\title{
除草剤連用によるクログワイ地上部の生育抑制の 判定指標と塊茎の形成*
}

\author{
稲村 達也**
}

要 約: クログワイ (Eleocharis kuroguwai Ohwi) に有効な除草剤を 3 年連用し，地上部の生育抑制と 新塊茎の形成抑制との関係並びに旧塊茎に及ぼす影 響を検討した。その結果，次のようなことが明らか になった。

1. クログワイ地上部生育の抑制程度の判定法と して, 株数と平均草丈の積の対無処理区比（地上部 指数）が有効であった（第 3 表）。

2. 地上部指数が小さいほど，すなわち地上部生 育の抑制程度が大きいほど新塊茥の形成数は減少 し，その傾向は除草剤連用の年数にかかわらず一定 であった（第 4 表）。

3. 新塊茎数の形成抑制率は形成深度で異なり, 第 2 層（5１0 cm）が大きく，次いで第 1 層（地表 $\sim 5 \mathrm{~cm})$ となり，第 3 層 $(10 \sim 15 \mathrm{~cm})$ からは深くな るほど抑制率は小さくなった（第 2 図）。

4. 地上部の生育抑制により，表層に形成される 新塊茎は小型化し，各層に形成される塊茥の重量と 仮比重の低下が認められた（第 $3,4,5$ 図）。

5. 旧塊茥は前年の新旧塊茥のうちから構成され るが, 当年の地上部指数は当年秋期に存在する既萌 芽旧塊茎の仮比重の低下に関与すると考えられた （第 5 表，第 5,6図）。

キーワード : 雑草防除, クログワイ, 除草剂, 地上 部, 塊茎形成

\section{緒言}

クログワイはオモダカとともに発生面積が著しく 増加しつつあり，水稲栽培において最も防除が困難 な雑草の一つとなっている。その原因として，主な

\footnotetext{
* 一部は日本雑草学会第 29 回（1990 年 4 月）講演会におい て発表した。

**奈良県農業試験場

(1991 年 10 月 18 日受理)
}

発生源である塊茎からの特有な発生生態 ${ }^{1,6,13)}$ があ げられる。

クログワイの徹底防除法の確立のためには，地上 部の生育抑制と塊茥の動態との関係を量的・質的両 面から長期にわたり追跡, 解明することが重要と考 えられる ${ }^{3,4)}$ 。クログワイに対する除草剤の作用性試 験9 11) は数多くあるが, 各々の除草剂との関係に重 点を置いたものが大部分である。そのため試験結果 が薬剂やその処理法に左右され，普遍性，共通性に 乏しく応用場面が限られていた。つまり，前述の著 者らの観点にたち，塊茥の動態を間接的な方法で的 確に評価できる普遍的な除草効果の判定法の策定に は至っていない。そして，地上部抑制下に打ける塊 茎の動態をクログワイ自然発生直場の調査から検討 した事例 2 4) はきわめて少ない。

そこで本研究は，クログワイ自然発生圈場で有効 除草剂の 3 年連用と塊茥の掘り取り調査を実施し, 地上部生育の抑制程度を総合的に示す指標を検討す ることとした。併せて, 地上部の生育抑制と新塊茎 の形成抑制および塊茥の充実度との関係，並びに旧 塊荎に及ぼす影響を検討した。

\section{材料および方法}

\section{1. 試験区の構成と耕種概要}

試験区の構成と除草剂処理法を第 1 表に示した が, 除草剂の 3 年連用試験は 1987 年から 1989 年の 試験 I と 1988 年から 1990 年の試験 II の 2 試験に 分け, クログワイが自然発生する奈良県農業試験場 の 16 号水田で実施した。供試水田に発生するクログ ワイは，小林による分類 ${ }^{6)}$ と比較し水田群と判断し た。すなわち，草丈は水稲と同程度となり，比較的 小型の塊茥を 9 月上旬から水稲が収穫される 10 月 上旬まで多数形成した。

試験 I, II はクログワイ対象としてそれぞれ 3 な いし 4 の体系処理法からなり, これらの処理を 3 年 
第 1 表＼cjkstart調查戋場の除草剤処理法

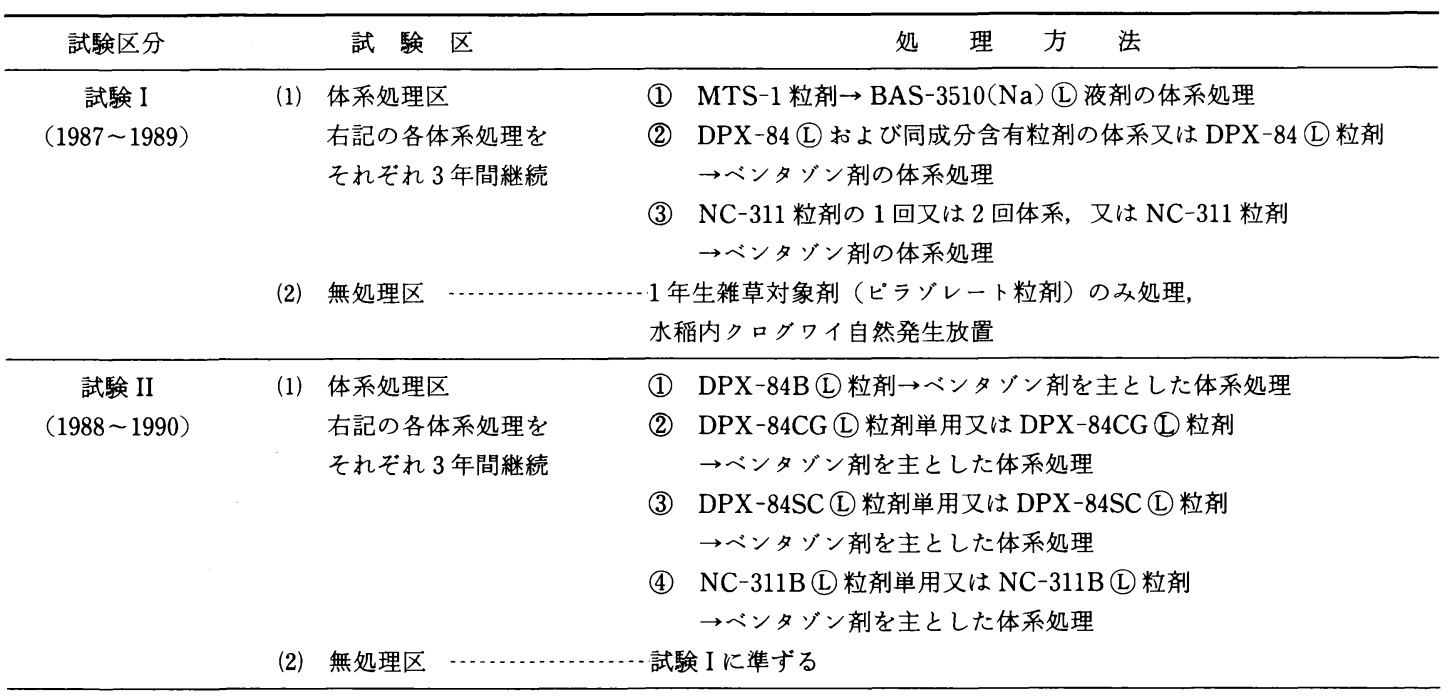

注）1. 処理区によっては，一年生雑草に有効な初期剤を適宜処理した。

2. MTS-1 : CNP 9\%+ダイムロン 7\%, BAS-3510(Na) LD：ベンタンゾン Na 塩 40\%, DPX-84 (L): へ ンスルフロンメチル $0.17 \%$, ベンタゾン剂：ベンタゾン単剤又は混合剤, NC-311：ピラゾスルフロンェチル

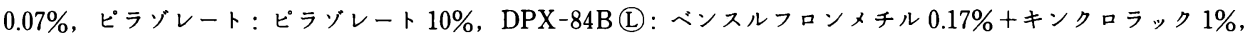
DPX-84CG (D) : ベンスルフロンメチル 0.17\%+プレチラクロール $2 \%, \mathrm{DPX}-84 \mathrm{SC} \mathbb{D}:$ ベンスルフロンメチル

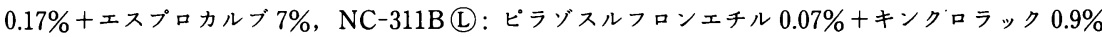

間継続し，処理区は $2 \mathrm{~m} \times 1.5 \mathrm{~m}$ の 2 区制とした。無 処理区は 3 年間クログワイの自然発生状態を保った が，他雑草との競合を除くためピラゾレート剤を処 理し, $1.2 \mathrm{~m} \times 1.5 \mathrm{~m}$ の規模で 1 体系処理法当り 2 な いし 3 区設定した。

土層中の塊茥形成位置の擋乱を防ぐため，水稲の 移植前の耕起は表層 $5 \mathrm{~cm}$ 程度とした。水稲品種「木 ウレイ」を 6 月 15 日に移植し，中干しは実施せず， 秋の落水は 9 月 20 日頃行い, 収穫は 10 月 5 日とし た。窒素成分で, 基肥 $5 \mathrm{~kg} / 10 \mathrm{a}$, 穂肥 $2.5 \mathrm{~kg} / 10 \mathrm{a} 2$ 回施用した。

\section{2. 調查方法}

地上部の調査は各々の体系処理区のクログワイ全 株数と最長株 10 株の草丈を除草剂連用 3 年間とも 9 月 20 日前後に測定した。1989 年は試験 I の各試験 区 $0.25 \mathrm{~m}^{2}$ について, 塊茎形成始期 (9 月 2 日), 盛期 (9月 19 日) 扣よび終期（10月 11 日）に地上部を抜 き取り, 株数, 茎数, 草丈および地上部風乾重を測 定した。

塊茎の掘り取り調査は, 除草剂連用 2,3 年目の 10 月 10 日前後に処理区 $0.7 \mathrm{~m}^{2}\left(1988\right.$ 年は $\left.1 \mathrm{~m}^{2}\right)$, 無処
理区 $0.25 \mathrm{~m}^{2}$ について実施した。掘り取りの深さは, 地表面から深さ $5 \mathrm{~cm}$ 毎に $25 \mathrm{~cm}$ までとし, 地表面 から順次第 1 層, 第 2 層, 第 3 層, 第 4 層および第 5 層とした（第 1 図)。層別に区分した土壌中から塊 茥を回収し，塊茎の色から新旧を区分し，塊茎数，塊 茎赤道面の直径および塊茎生体重を測定した。

地上部の抑制程度を判定する指標として以下のよ らな方法を用い,地上部指数と呼称することとした。

地上部指数 $=$

処理区の $\mathrm{m}^{2}$ 当り株数 $\times$ 平均草丈 $\times 100$ 無処理区の $\mathrm{m}^{2}$ 当り株数 $\times$ 平均草丈 $\times 100$

\section{結果}

\section{1. クログワイの発生量の推移}

無処理区におけるクログワイ塊茥形成期の草丈は 80 ９5 cm で 3 年とも大差はなかったが，株数は 2 年目に急増し，年次を経るほど増加した。新塊茎数 は試験 I 3 年目でやや減少したが，試験 II では $35 \%$ ほど増加した。旧塊茎数は両試験とも 3 年目で 著しく多くなった。処理区に打ける草丈は試験 I で 年次を経るほど低くなったが，試験 II では 3 年目で 


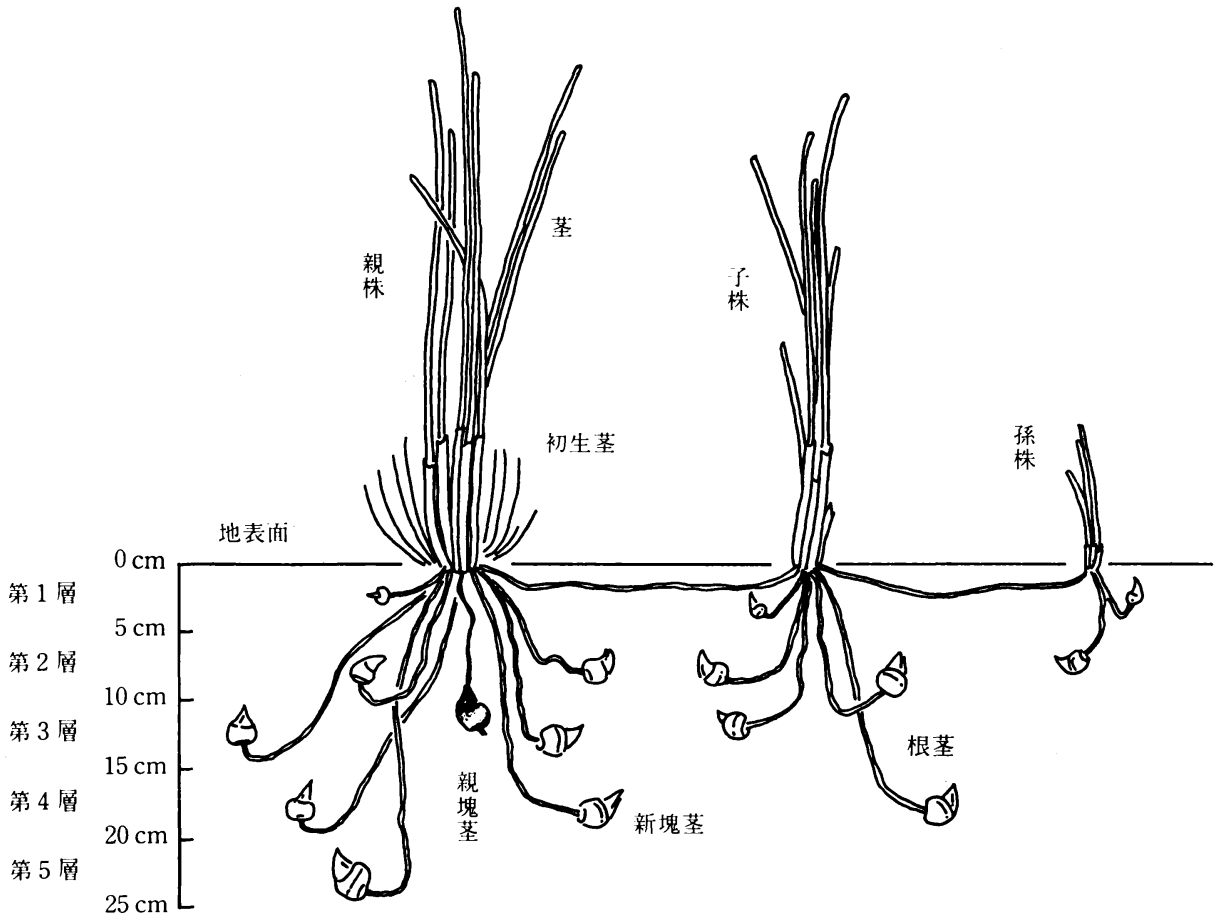

第 1 図 クログワイの増殖様式と掘り取り調查の層位

第 2 表 クログワイ塊茎形成期の草丈，株数および塊茎数の推移

(1987-1990 年)

\begin{tabular}{|c|c|c|c|c|c|c|c|c|c|c|c|}
\hline \multirow{2}{*}{\multicolumn{2}{|c|}{ 試験区分 }} & \multicolumn{3}{|c|}{ 草 丈 cm } & \multicolumn{3}{|c|}{ 株 数 $/ \mathrm{m}^{2}$} & \multirow{3}{*}{$\begin{array}{c}\begin{array}{l}\text { 新塊茎数 } \\
2 \text { 年目 }\end{array} \\
594\end{array}$} & \multirow{3}{*}{$\begin{array}{c}\text { 個 } / \mathrm{m}^{2} \\
3 \text { 年目 } \\
528\end{array}$} & \multirow{3}{*}{$\begin{array}{l}\text { 旧塊茎数 } \\
2 \text { 年目 }\end{array}$} & \multirow{3}{*}{$\begin{array}{c}\text { 個 } / \mathrm{m}^{2} \\
3 \text { 年目 } \\
42\end{array}$} \\
\hline & & \multirow{2}{*}{$\frac{1 \text { 年目 }}{84.7}$} & \multirow{2}{*}{$\begin{array}{r}2 \text { 年目 } \\
83.3\end{array}$} & \multirow{2}{*}{$\frac{3 \text { 年目 }}{93.1}$} & \multirow{2}{*}{$\begin{array}{c}1 \text { 年目 } \\
35.9\end{array}$} & \multirow{2}{*}{$\begin{array}{l}2 \text { 年目 } \\
219.8\end{array}$} & \multirow{2}{*}{$\frac{3 \text { 年目 }}{236.9}$} & & & & \\
\hline 試験 I & 無処理 & & & & & & & & & & \\
\hline & 処 理 & 55.9 & 34.7 & 32.4 & 7.5 & 5.4 & 4.1 & 20 & 11 & 6 & 5 \\
\hline \multirow[t]{2}{*}{ 試験 II } & 無処理 & 82.4 & 96.4 & 96.2 & 60.3 & 232.1 & 427.1 & 703 & 960 & 30 & 64 \\
\hline & 処 理 & 64.9 & 64.6 & 61.8 & 30.3 & 24.6 & 24.2 & 147 & 87 & 20 & 18 \\
\hline
\end{tabular}

注）1. 地上部調査は 9 月 20 日前後, 塊宔調査は 10 月 10 日前後に実施。 2 . 試験 I は $1987,88,89$ 年, 同 II は 1988,89 , 90 年の結果。3. 処理は全処理区を平均した。4. 新塊茎数は当年に形成された塊茎数, 旧塊茎数は前年に形成 された塊茎と前々年までに形成され萌芽能力のある塊茎の総数。

わずかに低下したのみであった。また株数は，両試 験とも 2 年目で減少し 3 年目は前年とほぼ同数で あった。新塊茥数は両試験とも 3 年目で著しく減少 し，旧塊茎はわずかに減少した（第 2 表）。

本試験に用いた圑場は，クログワイの発生が極め て多い圑場であったが，各試験区とも発生はほぼ均 一で試験の遂行上に支障はないと判断された。

\section{2. クログワイの地上部抑制程度の判定法}

除草剤の種類やその処理法によるクログワイの地 上部生育の抑制程度を総合化，一般化して示す判定
法を策定するため, 第 3 表に示す 5 要因を塊茎形成 時期別に測定し，最終的に生産された新塊茎数との 相関関係からそれらの有効性を検討した。

塊茎形成盛期および後期において，地上部指数と 新塊茎数との間には有意な相関が認められた。一方, 他の 4 要因では塊茎形成始期に打いて草丈と新塊茎 数との間に有意な相関が認められたにすぎなかっ た。このことから, 地上部生育の抑制程度の判定指 標として他の 4 要因を単独で使用するのは適切では なく, 塊茎形成盛期以降に測定された $\mathrm{m}^{2}$ 当り株数 
第 3 表 新塊茎数と塊茎形成時期別の各地上部形質との相関係数

(1989 年)

\begin{tabular}{cccccc}
\hline 塊茎形成時期 & $\mathrm{m}^{2}$ 当り株数 & $\mathrm{m}^{2}$ 当り茎数 & 草丈 & 地上部指数 & $\mathrm{m}^{2}$ 当り地上部乾物重 \\
\hline 始 期 & 0.308 & 0.125 & $0.625^{*}$ & 0.527 & 0.498 \\
盛 期 & 0.380 & -0.006 & 0.376 & $0.620^{*}$ & 0.405 \\
終 期 & 0.287 & -0.217 & 0.429 & $0.720^{*}$ & 0.359 \\
\hline
\end{tabular}

注）1. 地上部形質は塊茎形成始期 9 月 2 日，同盛期 9 月 19 日，同終期 10 月 11 日の各々調査。新塊茎数は 10 月 11 日に調査。 2. 地上部指数は $\mathrm{m}^{2}$ 当り株数 $\times$ 平均草丈の対無処理区比。3. * : 有意水準 $5 \%$ で有意。
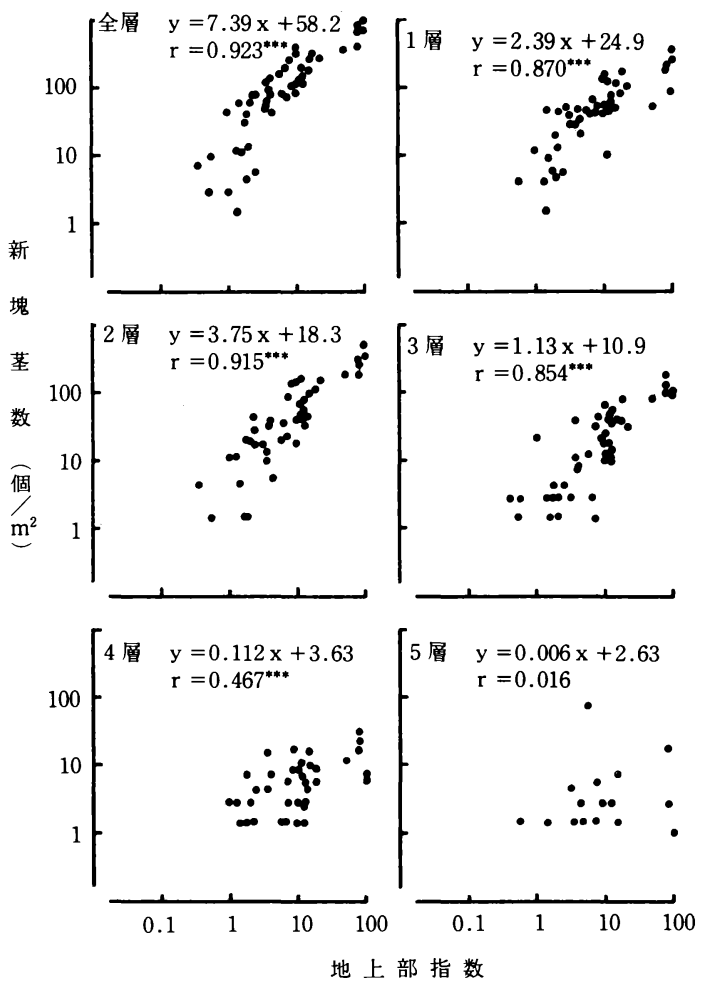

第 2 図 形成深度別に見た地上部指数と新塊茎数との関 係 (1989-90)

注) 1 . 地上部指数は $\mathrm{m}^{2}$ 当り株数 $\times$ 平均草丈の対無処 理区比。

2. 層位は地表より $5 \mathrm{~cm}$ 間隔, 第 1 図に準ずる。

3.***: 有意水準 $0.1 \%$ で有意。

および草丈を総合した $\left\{\left(\right.\right.$ 処理区の $\mathrm{m}^{2}$ 当り株数 $\times$ 平 均草丈) $/\left(\right.$ 無処理区の $\mathrm{m}^{2}$ 当り株数 $\times$ 平均草丈) $\} \times$ 100 の式で示される地上部指数 (仮称) が有効である と言える。従って以後, 薬凪や処理法によるクログ ワイ地上部生育の抑制程度の判定法として, 塊茥形 成盛期以降に測定された地上部指数（以下，塊茥形 成期の地上部指数または地上部指数と略）を使用す ることとした。

\section{3. クログワイの地上部の生育抑制と新塊茎の動 態との関係}

(1) 新塊茥の形成抑制

塊茎形成期の地上部指数と新塊茎数との間には有 意な直線関係が認められ(第 2 図), 塊茎形成期の地 上部の生育抑制が新塊茎の形成に強く影響してい た。さらに第 4 表に示したように試験 I, II とも除草 剂の連用処理における年次間において回帰直線の傾 きおよび高さに有意な差がなく，両回帰直線は同一 と見なせた。しかし，試験 I と試験 II の間において は回㷌直線の傾きが異なり，両回帰直線を同一と見 なせなかった（第 4 表）。

（2）土層深度別の新塊茎数の形成抑制

塊茎形成期の地上部の生育抑制による新塊茎の形 成抑制を形成深度別に示したものが第 2 図である。 第 1 層から第 4 層にかけて両者の間に $0.1 \%$ 水準で 有意な直線関係が認められたが，第 5 層では有意な 関係が認められなかった。そして，地上部指数に対 する新塊茎数の回帰の傾き, つまり地上部指数で見 た新塊茎形成数の減少率は形成深度で異なった。第 2 層が大きく, 次いで第 1 層, 第 3 層の順に小さくな り, 第 4 層では非常に小さくなった。また, 地上部 生育の抑制が顕著（地上部指数 $1 \%$ 前後）になると 形成深度間の新塊茎数の差がほとんどなくなった。

（3）土層深度別の新塊茎の大きさ执よび重量

塊茎形成期の地上部の生育抑制により新塊茎の小 型化が予想されたため ${ }^{3 \sim 5)}$, 塊茎形成期の地上部指数 と新塊茎の平均直径との関係を形成深度別に整理し た(第 3 図)。地上部の生育抑制が弱い場合および第 3 層より深い層では地上部の生育抑制による塊茎の 明瞭な小型化は認められないが, 第 1,2 層では両者 の間に有意な 1 次の相関関係が認められた。なお,地 上部の生育抑制による新塊茎直径の小型化傾向は, 第 1 層が第 2 層に比較してわずかに強かった。

塊茎形成期の地上部指数之平均新塊茎重との関係 
第 4 表 除草剂連用処理区に打ける新塊茎数（y）の地上部指数（x）に対する直線回㷌 （1988-1990 年）

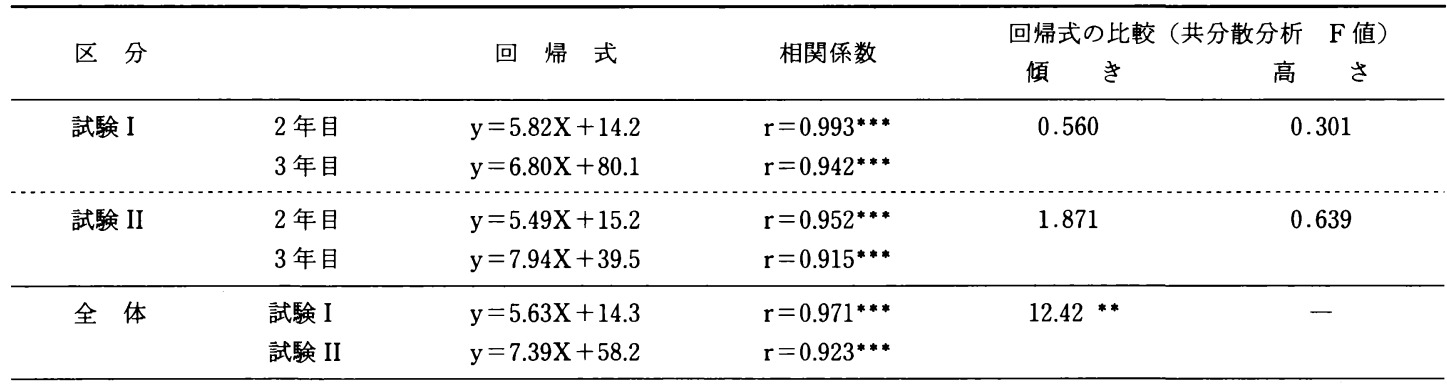

注）1. 全体の試験 I と試験 II の回帰式は処理 2 年間を込みにして求め, 両回帰式の傾きが異なるため高さの比較は実施 せず。

2. ${ }^{* * * * * *}$ : 有意水準 $1 \%, 0.1 \%$ で有意。
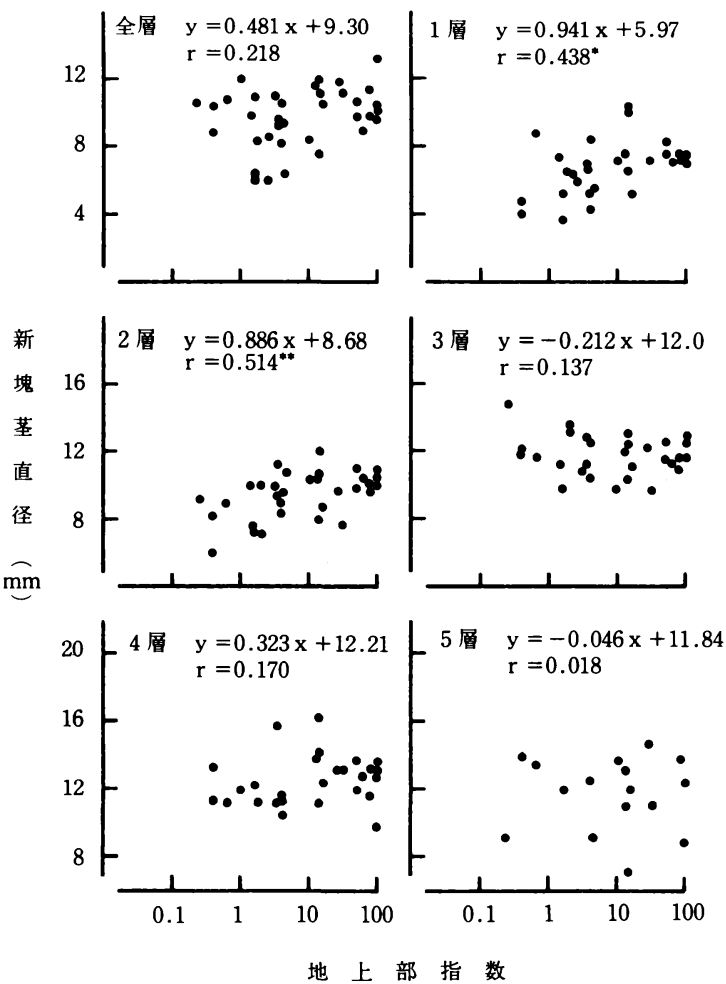

第 3 図形成深度別に見た地上部指数と新塊茎の直径と の関係 (1988-90)

注）*** : 有意水準 $5 \%, 1 \%$ で有意。

を形成深度別に示したものが第 4 図である。第 3 層 を除く各層で両者の間に有意な 2 次の相関関係が認 められ，地上部生育の抑制程度に応じて新塊茎が軽 量化し,特に地上部指数 $10 \%$ 程度を境に軽量化が顕 著であった。

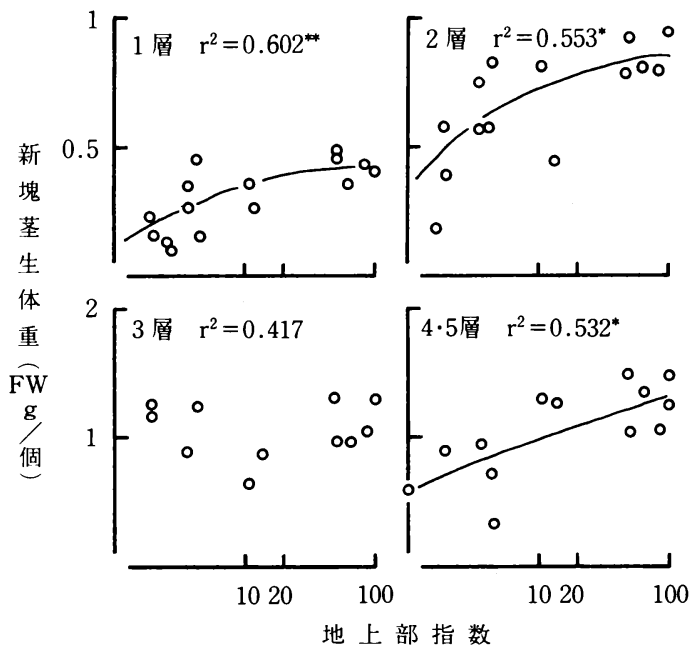

第 4 図 形成深度別に見た地上部指数と平均新塊茎重と の関係 (1989-90)

注） ${ }^{*, * *}$ : 有意水準 $5 \%, 1 \%$ で有意。

（4）新塊菱の仮比重

塊茎形成期の地上部指数と新塊茎の充実度を示す と考えられる仮比重との関係を形成深度別に第 5 図 に示した。仮比重と地上部指数との間には，第 1 層 から第 3 層まで有意な 2 次の相関関係が，第 4,5 層 では有意な一次の相関関係がそれぞれ認められた。 そして, 第 1 層から第 3 層までは地上部指数 $10 \%$ 以 下で仮比重が急減する傾向がみられた。

4.クログワイの地上部の生育抑制と旧塊龩の動 態との関係

（1）旧塊茎数に影響を及ぼす特性

塊茎形成期の地上部の生育抑制と旧塊茎数との関 


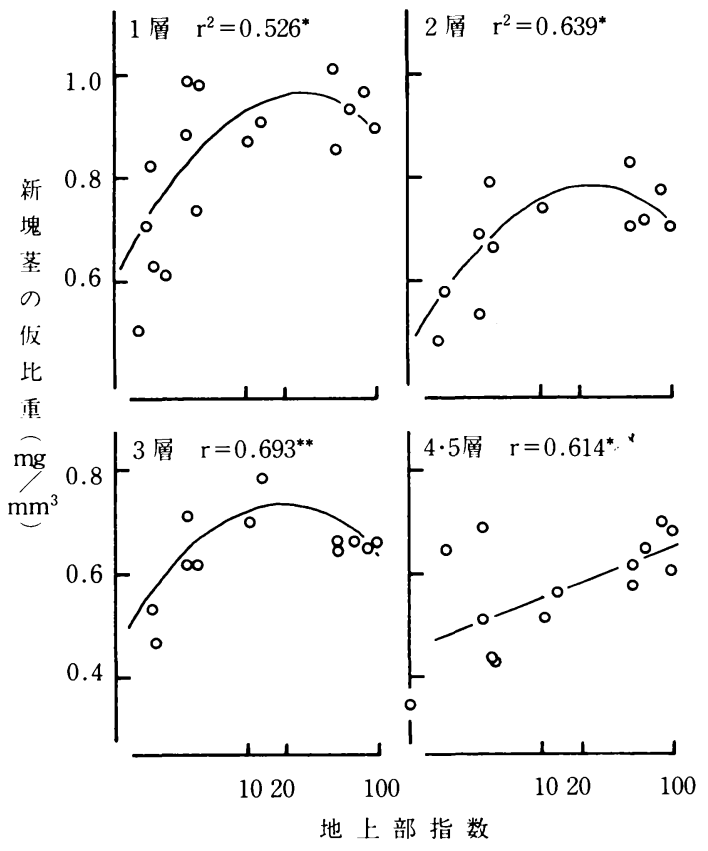

第 5 図 形成深度別に見た地上部指数と新塊茎の仮比重 との関係 (1989-90)

注） 1 . 仮比重 $=$ 新塊茎重 $(\mathrm{mg}) /$ 新塊茎の直径 $(\mathrm{mm})$ の 3 乗。

2. ${ }^{* * * *}$ : 有意水準 $5 \%, 1 \%$ で有意。

係を検討するため, 当年の新塊茎数，前年に形成さ れた塊茎数，前々年までに形成され前年において萌 芽能力を有する前年の旧塊茥数および当年と前年の 地上部指数を選定し，これらと前年までに形成され 当年に打いて萌芽能力を有する当年の旧塊茥数との

第 $\mathbf{5}$ 表 当年の旧塊茎数と各項目間の偏相関係数 (1987-1990 年)

\begin{tabular}{llllll}
\hline & $\begin{array}{l}\text { 当年の } \\
\text { 新塊茎 }\end{array}$ & $\begin{array}{l}\text { 前年形 } \\
\text { 数の塊 } \\
\text { 茎数(A) }\end{array}$ & $\begin{array}{l}\text { 前年の } \\
\text { 旧塊茥 } \\
\text { 数(B) }\end{array}$ & $\begin{array}{l}\text { 当年の } \\
\text { 地上部 } \\
\text { 指数 }\end{array}$ & $\begin{array}{l}\text { 前年の } \\
\text { 地上部 } \\
\text { 指数 }\end{array}$ \\
\hline 試験 I & 0.073 & 0.442 & $0.951^{* * *}$ & -0.136 & -0.243 \\
試験 II & 0.184 & $0.404^{*}$ & $0.452^{*}$ & -0.028 & -0.178 \\
I, II 込2 & 0.108 & $0.356^{*}$ & $0.433^{* *}$ & -0.011 & -0.188 \\
\hline
\end{tabular}

注）1. 前年形成の塊茎：前年に形成された塊茎の内, 前 年秋期において萌芽力を有する塊茎。

2. 前年の旧塊茎：前々年までに形成された塊茎の 内, 前年秋期において萌芽力を有する塊茎。

3. 当年の旧塊茎 : 前年までに形成された塊茎 $(A+$ B)の内, 当年秋期において萌芽力を有する塊茥。 4. *******: 有意水準 $5 \%, 1 \%, 0.1 \%$ で有意。



地上 部 指 数

第 6 図 形成深度別に見た地上部指数と旧塊茎の仮比重 との関係 $(1989-90)$

注） 1. 仮比重 $=$ 旧塊茎重 $(\mathrm{mg}) /$ 旧塊菱の直径 $(\mathrm{mm})$ の 3 乗。

2. 地上部指数は旧塊茎を掘り取った当年のもの。

間の偏相関係数を求め第 5 表に示した。試験 I では, 当年の旧塊茎数は前年の旧塊茎数との間に有意な偏 相関が認められ，前年に形成された塊茎数との間に は有意差は小さいがある程度の偏相関係数の值が得 られた。そして，試験 II および両者を込みにした全 体では，当年の旧塊茎数は前年に形成された塊茎数 並びに前年の旧塊茎数との間に有意な偏相関が認め られた。しかし，当年の旧塊茎数と前年および当年 の地上部指数との間には有意な偏相関は認められな かった。

（2）旧塊茎の仮比重

1989 年, 1990 年それぞれの年における塊茎形成期 の地上部指数と旧塊茥の仮比重との関係を形成深度 別に第 6 図に示した。旧塊茎の仮比重は新塊茎のそ れより低く，地上部の生育抑制による仮比重の低下 が新塊茎の場合より緩やかで，形成深度によっては あまり影響を受けない場合も見られた。

\section{考察}

クログワイの主な繁殖源である塊茎の形成阻害に は塊茎形成期に打ける地上部の切除 ${ }^{12)}$ や枯殺8) が 
有効で, 除草剤の効果判定も塊茎形成期に行らべき である。除草効果の判定には, 達観調查による枯死 程度 ${ }^{8 \sim 10)}$, 残草乾物重 ${ }^{5)}$, 株数 ${ }^{13)}$ および草高 ${ }^{7)}$ 等が使 用されてきた。

本報告では塊茎形成期に扮けるクログワイの株数 と平均草丈の積の対無処理区比を地上部指数之呼称 し, 地上部生育の抑制程度の判定指標として使用す ることとした。塊茎形成盛期以降に測定された地上 部指数は, 塊茎の動態の重要な要素である新塊茎数 の地上部抑制下に抢ける有効な評価法として利用で きることが明らかとなった(第 3 表)。地上部指数が 塊茎の動態を間接的に表す有効な指標となる主な原 因は，塊茎形成を支配する根茎がある程度の長さを 有する充実した茎の基部に分化すること，そして薬 剂がクログワイの株数増加と草丈伸長の両者に相加 的抑制効果を及ぼすためと考学られる。また処理区 で塊茎形成が遅延年するため無処理区の塊茎形成盛 期以降に測定された地上部指数が有効になると判断 された。なお，地上部指数の有効性については，次 報以降で深く解明する。

次に, 新塊茎の形成数は塊茎形成期の地上部指数 に応じて抑制され，この関係は連年施用における処 理年次間で差異がなく地上部の生育抑制に応じて一 定の傾向で新塊茎数が減少した（第 4 表）。また第 2 表から求めた地上部指数は試験 I で 1 年目 $24 \%, 2$ 年目 $1.4 \%, 3$ 年目 $0.6 \%$, 試験 II で同 $40 \%, 7.1 \%$, $3.6 \%$ と年々減少し, 除草剂の連年施用による新塊荎 形成数の経年的減少は地上部指数が年々減少する結 果の反映と見られた。

第 2 図で論じたように地上部指数で見た新塊茥数 の形成抑制率は形成深度で異なった。これは根茎長 にクローン間変異 ${ }^{6}$ が見られるよ5に, 塊茎を形成 した根茎の長さと数が地上部の生育抑制により变化 するためと推察された。つまり地上部の生育抑制に より塊茎を形成する総根茥数は減少するが, 深い層 に分布できる塊茥を形成した根茎の数はあまり減少 しないためと考えられた。また地上部指数の減少に ともない第 3 層より深い層に形成される塊茎は小型 化しないこと（第 3 図）からも, 深い層に伸長し大 型塊茥を形成する根茎の分化・伸長およびその塊茥 直径の増大が，水稲無栽植区の場合 ${ }^{6)}$ と同様に浅い 層に対して優先されることが示唆されている。

塊茎の大きさとの関係を第 3 図以下に述べたが,
地上部指数の減少にともない新塊茎の仮比重が急激 に低下する変曲点が第 1 3 層の地上部指数 $10 \%$ 付 近に存在すること, 第 4,5 層では仮比重が直線的に 低下寸ることが第 5 図から明らかになった。

第 1 3 層の弱い地上部の生育抑制による仮比重 の増大は塊茎数の減少によるものと見られ，無処理 に拉ける仮比重の低下は多数形成された塊茎による 養分競合のためと判断された（第 2，5図）。また第 2 図に示されたように，第 1 3 層に怙ける地上部指 数 $10 \%$ 付近からの仮比重の急激な低下は, 地上部生 育の著しい抑制のため炭酸同化産物の供給が一段と 不足し，塊茎の充実に影響したためと思われる。さ らに第 4, 5 層では塊茎重が緩やかに低下しているこ とから, 同化産物の分配は深い層に形成される塊茎 に優先して行われることが考えられた。

旧塊茎は前年の新旧塊茎のらちから構成され, 当 年秋期に生存している旧塊茎の内, 当年春期に打い て萌芽・再萌芽したものは除草剤処理の影響を受け 当年の地上部の生育抑制と関係があると考えられ た。しかし，当年秋期に打ける旧塊茎数は当年の地 上部指数と関係が認められず(第 5 表), 生存する旧 塊茎がすべて未萌芽塊茎とは考えられないことから 地上部の生育抑制の影響は既萌芽旧塊茎の他の形質 に現われると推察される。つまり，塊茎の充実度を 示すと考兄られる仮比重は各形成深度とも新塊茥に 比較して旧塊茎で低く(第 5,6 図)，既萌芽旧塊茎で は維持呼吸に加え地上部の生育抑制による養分消耗 が仮比重をさらに低下させる一因と考えられた。

謝 辞: 本研究を行らにあたり, 最も重要で多労 を要した塊茎の掘り取り調査にご協力いただいた除 草剤関係各社ならびに関係諸氏に深く感謝いたしま す。

\section{引用 文 献}

1）本間豊邦・伊藤一幸・渡辺 泰 1981。 クログワイ 塊茎の萌芽特性について。雑草研究 26 (別), 53-54.

2）船越安信・南保俊夫・汇田貞文・棉原昌弘・日比佐 和子・榎本裕司 1988 . 水田除草剂 MT-128 の作 用性 (第 2 報). 雑草研究 33 (別), 51-52.

3）稲村達也・渡辺英信・徳山博康 1989 . 除草剂連用 によるクログワイ塊茎の形成抑制。近畿作育研究 
34, 35-38.

4）稲村達也 1989 . 除草剂連用によるクログワイ徹 底防除の可能性. 農及園 64(8)，945-950.

5）伊藤一幸・宮原益次 1986 。 クログワイに対する 除草剂連用の効果. 雑草研究 31(別), 141-142.

6）小林央往 1984 . 水田多年生雑草クログワイの生 態と変異. 雑草研究 29, 1-15.

7）小山 豊・山岸 淳・穴倉豊光・深山政治・武市義 雄 1986. 水田多年生雑草才モダカの生態とその 防除 第 1 報。千葉農試研報 27, 167-183.

8）中川恭二郎・宮原益次 1967 . ミズガヤッリとク ログワイに対する数種除草剤の雑草処理における 殺草性について. 雑草研究 6, 107-111.

9）鈴木計司・大塚一雄・塩原比佐雄・小川信太郎
1983. クログワイ塊茎の土中深度と薬剤の体系 処理効果. 雑草研究 28(別), 175-176.

10）土田邦夫・柴谷得郎・小沢哲男 1988. 水田多年生 雑草の防除に関する研究第 1 報. 雑草研究 33 (別)，83-84.

11）土田邦夫・柴谷得郎・小沢哲男 1988. 水田多年生 雑草の防除に関する研究第 2 報. 雑草研究 33 (別)，85-86.

12）植木邦和・中村安夫・小野誠一 1969. 多年生雑草 クログワイの防除に関する基礎的研究 第 1 報. 雑草研究 8,50-56。

13）山岸 淳・武市義雄 1978. 水田多年生雑草防除 に関する研究 第 VIII 報.千葉農試研報 19,191217.

\section{Relationship between Tuber Formation and the Control of Aerial Parts of Eleocharis kuroguwai Ohwi by the Application of Herbicides for a Three Year Period}

Tatsuya Inamura*

\section{Summary}

The control of old tubers and the relationship between the control of aerial parts and formation of new tubers were analysed in field experiments in which herbicides were applied for a three year period to the water chestnut, Eleocharis kuroguwai Ohwi. The results are as follows;

1. The control index, which is the ratio of the product of the number of hills and length of the weed plant in the herbicide-treated plots against that in the untreated control plot, was correlated with the degree of control of the aerial parts (Table 3).

\footnotetext{
* Nara Prefectural Agricultural Experiment Station,
} Kashihara, Nara, 634
2. The number of new tubers decreased when the aerial parts of weed were controlled. The decreasing rates were statistically equivalent during the experimental years (Table 4 ).

3. The decreasing rate of the new tubers at the time of the control of the aerial parts was high at the $0-15 \mathrm{~cm}$ depth, but very low at the $15-25 \mathrm{~cm}$ depth of soil layers (Fig. 2).

4. By controlling the aerial parts of the weed, the average diameter of the new tubers in the soil layers at the $0-10 \mathrm{~cm}$ depth became smaller, and the average specific gravity and average weight at the $0-25 \mathrm{~cm}$ depth decreased (Fig. $3,4,5$ ).

5. The old tubers consisted of newly-formed ones and of their which had survived in the preceding years. The decrease of the specific gravity of the old tubers was considered to be caused by the growth inhibition of the aerial parts (Table 5, Fig. 5, 6).

Key words : weed control, water chestnut, herbicide, aerial part, tuber formation 